\title{
Effect of Growing Intercrops on Growth and Yield of Tree Mulberry in turn its Influence on Cocoon Yield
}

\author{
Rajegowda $^{1 *}$, B. S. Vinutha ${ }^{1}$, C. Vanitha ${ }^{1}$ and V. B. Sanath Kumar ${ }^{2}$ \\ ${ }^{1}$ Krishi Vignan Kendra, Kandali, Hassan- 573 102, \\ University of Agricultural Sciences, Bengaluru, India \\ ${ }^{2}$ Department of Plant Pathology, Agriculture College, Mandya \\ University of Agricultural Sciences, Bengaluru, India \\ *Corresponding author
}

\section{A B S T R A C T}

\section{Keywords}

Tree Mulberry, Intercrops, Leaf yield, Cocoon yield, Additional Income

Article Info

Accepted:

26 April 2020

Available Online:

10 May 2020
The study was conducted during 2017- 2019 in Katharighatta and Jodighatta village of Channarayapatna Taluk, Hassan District by the intervention of Krishi Vignan Kendra, Kandali, Hassan as a part of On Farm Test to evaluate the effect of growing intercrops on growth and yield of Tree Mulberry. The experiment was laid out in RCBD with 5 replications and 4 treatments which includes $\mathrm{T}_{1}$ (Sole Tree mulberry) as control, $\mathrm{T}_{2}$ (Tree mulberry + Ragi), $\mathrm{T}_{3}$ (Tree mulberry + Groundnut) and $\mathrm{T}_{4}$ (Tree mulberry + Cowpea). The growth and yield parameters of Tree mulberry like average number of shoots/plant, shoot height $(\mathrm{cm})$, number of leaves/shoot and leaf yield $(\mathrm{Kg} / \mathrm{ha} / \mathrm{crop})$ were recorded significantly higher in $\mathrm{T}_{4}(45,120.34,29$ and 7955.82) as compared to control (31.64, 114.24, 24 and 7809.35), respectively. The cocoon yield attributes like larval weight(g), cocoon weight $(\mathrm{g})$, shell weight $(\mathrm{g})$, pupal weight $(\mathrm{g})$, shell ratio (\%) and cocoon yield (Kg/100 DFLs) were recorded higher in $\mathrm{T}_{4}(4.56,1.76,0.44,1.33,25.02$ and 70$)$ as compared to control $(4.54,1.71,0.43,1.32,24.94$ and 68.41), respectively. Growing Cowpea as an intercrop given higher B:C (2.63) due to increased soil fertility, higher leaf yield, cocoon yield and additional income as compared with other intercrops (Ragi- 2.56, Groundnut-2.46) and control (2.54).

\section{Introduction}

Sericulture is an art of scientific cultivation of mulberry and rearing silkworms where money flows from rich to poor. Mulberry, a sole food plant for silkworm, Bombyx mori L. is a deciduous or moist deciduous tree species originated from foothills of Himalayas which can survive and grow upto an elevation of $9000 \mathrm{msl}$. In fact, other than being used for sericulture, it also used in most of the public places, courtyards of the houses as a popular fruit tree. Sericulture is facing tough competition due to limited land resources and competition with other agricultural crops. Therefore, there is an urgent need to develop 
mutual harmony between sericulture and agriculture for of sustainable co-existence. In general most of the of the sericulture farmers have very small land holdings and depend mainly upon family labor and simple tools, they neither have the capacity to take risk nor have enough land to diversify the cropping system. Thus, by growing other of short duration crops, the farmer gets additional benefits from intercrops (Ahasn et al., 1989). In states like Karnataka, intercropping of tree mulberry at 10 x $10 \mathrm{ft}$ spacing with Ragi, Cowpea and Groundnut have maximum returns from sericulture and pulses thereby facilitating additional net gain from one acre of mulberry plantations during spring and autumn seasons. An additional income can easily be fetched by growing short duration crops. Lot of work has already been done for integration of Sericulture with agriculture and horticulture (Gargi et al., 1997). Intercropping of mulberry with saffron in Kashmir yielded a good quality of mulberry leaf from the same field Where saffron was cultivated alone to generate work as well as good deal of returns to farmers during lean period when there are no operations related to saffron cultivation (Kaur et al., 2002). Various recent studies also suggest that mulberry can successfully intercropped with medicinal plants like Aloe barbadense, Asparagus racemosa, Acoru scalamus (Madhusudan et al., 2015).

\section{Materials and Methods}

The study was conducted during the period of 2017-18 to 2018-19 in tree mulberry fields of farmers at Kathrighatta and Jodighatta villages of Channarayapatna Taluk, Hassan District. The farmers were selected through purposive sampling. This selection was based on the predominantly sericulture based families in the region. The experiment was laid out in Randomized Complete Block Design (RCBD) consisting of 4 treatments with 5 replications. In each year total of 5 farmers were selected with the land holdings of 0.4 ha and were considered as a replications. The farmer's practice which is solely grown tree mulberry without any intercrop considered as control (Sole Tree Mulberry, Treatment-1). The tree mulberry was cultivated with a short duration crops in between the rows as Ragi (KMR-301, Treatment-2), Groundnut (K-6, Treatment-3) and Cowpea (KBC-1, Treatment-4) during the period of the study. The farmers selected were interviewed and questioned on various socioeconomic parameters in order to obtain a baseline data about the economic status of the families before and after. The soil status was also recorded before and after the experimentation. The growth and yield parameters recorded on tree mulberry were number of shoots/plant, average shoot length height $(\mathrm{cm})$, average number of leaves/shoot and leaf yield (kg/ha/crop). The leaves from tree mulberry were fed to silkworms and yield attributes like larval, cocoon, shell and pupal weights $(\mathrm{g})$, shell ratio $(\%)$, cocoon yield $(\mathrm{Kg} / 100$ DFLs) and economics of tree mulberry leaf production with intercrops were also recorded during the course of study. The data collected on different parameters were statistically analyzed at 5\% level of significance (Russel, 1986).

\section{Results and Discussion}

\section{Soil fertility status}

The soil fertility status was enhanced in the soils where the intercrops were taken up as compared to sole cropping of tree mulberry. There was no change in the soil $\mathrm{pH}(7.2,7.12$, 7.14 and 7.11 in $\mathrm{T}_{1}$ i.e. control, $\mathrm{T}_{2}, \mathrm{~T}_{3}$ and $\mathrm{T}_{4}$, respectively). The electric conductivity was reduced in the soils where intercrops were taken up (6.8 to 6.5-6.7 (dS/m). There was an enhancement in organic carbon (0.50 to 0.60 $0.63 \%), \mathrm{N}$ (310.2 to $315.7-329.8 \mathrm{Kg} / \mathrm{ha}), \mathrm{P}$ (289.0 to $290.2-293.5 \mathrm{Kg} / \mathrm{ha}), \mathrm{K}$ (184 to 
188.5-190 Kg/ha), Zn (0.6 to 0.65-0.7 ppm) and $\mathrm{B}$ (0.5 to $0.52-0.53 \mathrm{ppm})$ from sole crop plot to intercrop plot (Table 1).

Growth and yield performance of tree mulberry

The number of shoots per plant was observed maximum in $\mathrm{T}_{4}$ (45) followed by $\mathrm{T}_{3}(35), \mathrm{T}_{2}$ (34) and least in $T_{1}$ i.e Control (31.6). The average shoot length $(\mathrm{cm})$ was recorded higher in $\mathrm{T}_{4}$ (120.34) followed by $\mathrm{T}_{2}$ (116.84), $\mathrm{T}_{1}$ and least in $\mathrm{T}_{3}$ (107.94). The average number of leaves per shoot was recorded high in $\mathrm{T}_{4}$ (29) followed by $\mathrm{T}_{3}(25)$ and low in $\mathrm{T}_{2}$ and control (24). The leaf yield ( $\mathrm{Kg} / \mathrm{ha} / \mathrm{Crop})$ was recorded maximum in case of $\mathrm{T}_{4}$ (7955.82) followed by $\mathrm{T}_{3}$ (7824.40), $\mathrm{T}_{1}$ Control (7779.34) and least in $\mathrm{T}_{2}$ that is 7635.07 (Table 2). These findings are supported by Shankar et al., 1998.

\section{Performance of silkworm reared on tree mulberry}

Among all the treatments the silkworm yield attributes like Larval (4.56 g), cocoon (1.76 $\mathrm{g})$, shell $(0.44 \mathrm{~g})$ and pupal weights $(1.33 \mathrm{~g})$, Shell ratio (25.01\%) and cocoon yield (70 $\mathrm{Kg} / 100$ DFLs) were found maximum in $\mathrm{T}_{4}$ as compared to control $(4.54 \mathrm{~g}, 1.71 \mathrm{~g}, 0.43 \mathrm{~g}$, $1.32 \mathrm{~g}$. $24.94 \%$ and $68.41 \mathrm{~kg} / 100$ DFLs), respectively (Table 3 ). Growing cowpea as intercrop in tree mulberry given more additional income and improved soil fertility (Table 1 and 4). The present findings are supported by the reports by Koul et al., (2008) and Singhvi and Katiyar (2009), who recommended the growing of mulberry with vegetables and leguminous crops as these don't require additional inputs. Also this finding is in line with (Bravo-Monroy et al., 2016; Current et al., 1995; De Souza Filho et al., 1999; Moreno and Sunding 2005) who found out that there was a positive and significant relation between economic return and espousal of agroforestry. Mushtaq Rasool Mir et al., (2018) reported the similar findings on efficacy of mulberry based intercropping system in the pirpanjal and shiwalik regions of Himalayas.

\section{Economics of tree mulberry leaf production with intercrops}

The total gross return (Rs/ha), net return (Rs/ha) and $\mathrm{BC}$ ratio were recorded highest in $\mathrm{T}_{4}(67779,42079,2.63)$ followed by $\mathrm{T}_{2}$ (24500, 38325, 2.56), $\mathrm{T}_{3}(57844,34344,2.46)$ due to higher leaf yield, cocoon yield and additional income from intercrop and least recorded in control i.e. $\mathrm{T}_{1}(38895,23595$, 2.54), respectively (Table 4). These findings are in conformity with Ashan et al., (1989), Kabir et al., (1991), Gargi et al., (1997), Dayakar Yadav and Nagendra Kumar (1998) and Shankar et al., (2000) where in significantly higher net returns and $\mathrm{BC}$ ratio were recorded in mulberry and legume intercropping system compared to sole mulberry.

Table.1 Soil fertility status before and after the cultivation of intercrops in tree mulberry

\begin{tabular}{|c|c|c|c|c|c|c|c|c|}
\hline $\begin{array}{c}\text { Soil fertility } \\
\text { status }\end{array}$ & $\mathbf{p H}$ & $\begin{array}{c}\mathbf{E C} \\
(\mathbf{d S} / \mathbf{m})\end{array}$ & $\begin{array}{c}\mathbf{O C} \\
(\mathbf{\%})\end{array}$ & $\begin{array}{c}\mathbf{N} \\
(\mathbf{K g} / \mathbf{h a})\end{array}$ & $\begin{array}{c}\mathbf{P} \\
(\mathbf{K g} / \mathbf{h a})\end{array}$ & $\begin{array}{c}\mathbf{K} \\
(\mathbf{K g} / \mathbf{h a})\end{array}$ & $\begin{array}{c}\mathbf{Z n} \\
(\mathbf{p p m})\end{array}$ & $\begin{array}{c}\mathbf{B} \\
(\mathbf{p p m})\end{array}$ \\
\hline Before & $\mathbf{7 . 2}$ & $\mathbf{0 . 6 8}$ & $\mathbf{0 . 5 0}$ & $\mathbf{3 1 0 . 2}$ & $\mathbf{2 8 9 . 0}$ & $\mathbf{1 8 4}$ & $\mathbf{0 . 6}$ & $\mathbf{0 . 5}$ \\
\hline After T1 & $\mathbf{7 . 1 2}$ & $\mathbf{0 . 6 7}$ & $\mathbf{0 . 6 2}$ & $\mathbf{3 1 5 . 7}$ & $\mathbf{2 9 3 . 5}$ & $\mathbf{1 9 0}$ & $\mathbf{0 . 7}$ & $\mathbf{0 . 5}$ \\
\hline T2 & $\mathbf{7 . 1 4}$ & $\mathbf{0 . 6 5}$ & $\mathbf{0 . 6 0}$ & $\mathbf{3 2 1 . 4}$ & $\mathbf{2 9 0 . 2}$ & $\mathbf{1 8 8 . 5}$ & $\mathbf{0 . 6 5}$ & $\mathbf{0 . 5 2}$ \\
\hline T3 & $\mathbf{7 . 1 1}$ & $\mathbf{0 . 6 5}$ & $\mathbf{0 . 6 3}$ & $\mathbf{3 2 9 . 8}$ & $\mathbf{2 9 1 . 4}$ & $\mathbf{1 8 9}$ & $\mathbf{0 . 6 6}$ & $\mathbf{0 . 5 3}$ \\
\hline
\end{tabular}


Table. 2 Growth and yield performance of tree mulberry

\begin{tabular}{|c|c|c|c|c|c|c|c|c|c|c|c|c|}
\hline \multirow[t]{2}{*}{ Treatments } & \multicolumn{3}{|c|}{$\begin{array}{c}\text { Number of shoots/ } \\
\text { plant }\end{array}$} & \multicolumn{3}{|c|}{$\begin{array}{l}\text { Average shoot length } \\
\text { (cm) }\end{array}$} & \multicolumn{3}{|c|}{$\begin{array}{c}\text { Average number of } \\
\text { leaves/shoot }\end{array}$} & \multicolumn{3}{|c|}{$\begin{array}{c}\text { Leaf yield } \\
\text { (Kg/ha/crop) }\end{array}$} \\
\hline & 2017-18 & 2018-19 & Pooled & 2017-18 & 2018-19 & Pooled & 2017-18 & 2018-19 & Pooled & 2017-18 & 2018-19 & Pooled \\
\hline T1 & 30.80 & 32.47 & 31.64 & 100.17 & 128.30 & 114.24 & 19.00 & 29.00 & 24.00 & 7329.71 & 8288.98 & 7809.35 \\
\hline $\mathbf{T} 2$ & 31.00 & 37.00 & 34.00 & 112.34 & 121.34 & 116.84 & 17.00 & 31.00 & 24.00 & 7435.58 & 7834.56 & 7635.07 \\
\hline T3 & 33.00 & 37.00 & 35.00 & 98.84 & 117.04 & 107.94 & 22.00 & 28.00 & 25.00 & 7514.59 & 8134.22 & 7824.41 \\
\hline T4 & 44.79 & 45.20 & 45.00 & 106.44 & 134.24 & 120.34 & 24.86 & 33.14 & 29.00 & 7676.10 & 8234.74 & 7955.42 \\
\hline SE.m \pm & 2.25 & 2.26 & 1.40 & 4.25 & 4.84 & 3.21 & 1.31 & 1.37 & 1.01 & 94.56 & 93.88 & 63.24 \\
\hline \multirow[t]{2}{*}{$\begin{array}{c}\text { CD } \\
(p=0.05)\end{array}$} & 6.94 & 6.96 & 4.33 & 13.09 & 14.90 & 9.90 & 4.03 & 4.22 & 3.11 & 291.38 & 289.26 & 194.85 \\
\hline & $*$ & $*$ & $*$ & $*$ & $*$ & $*$ & $*$ & $*$ & $*$ & $*$ & $*$ & $*$ \\
\hline
\end{tabular}

Table.3 Performance of silkworm reared on tree mulberry

\begin{tabular}{|c|c|c|c|c|c|c|c|c|c|c|c|c|c|c|c|c|c|c|}
\hline \multirow[t]{2}{*}{ Treatments } & \multicolumn{3}{|c|}{$\begin{array}{c}\text { Larval weight } \\
\text { (g) }\end{array}$} & \multicolumn{3}{|c|}{$\begin{array}{l}\text { Cocoon weight } \\
\text { (g) }\end{array}$} & \multicolumn{3}{|c|}{$\begin{array}{c}\text { Shell weight } \\
\text { (g) }\end{array}$} & \multicolumn{3}{|c|}{$\begin{array}{l}\text { Pupal weight } \\
\text { (g) }\end{array}$} & \multicolumn{3}{|c|}{$\begin{array}{c}\text { Shell ratio } \\
(\%)\end{array}$} & \multicolumn{3}{|c|}{$\begin{array}{l}\text { Cocoon yield } \\
\text { (kg/100 DFLs) }\end{array}$} \\
\hline & $\begin{array}{c}2017 \\
-18\end{array}$ & $\begin{array}{c}2018 \\
-19\end{array}$ & $\begin{array}{l}\text { Poole } \\
\text { d }\end{array}$ & $\begin{array}{l}2017- \\
18\end{array}$ & $\begin{array}{c}2018 \\
-19\end{array}$ & $\begin{array}{l}\text { Poole } \\
\text { d }\end{array}$ & $\begin{array}{c}2017- \\
18\end{array}$ & $\begin{array}{c}2018- \\
19\end{array}$ & $\begin{array}{c}\text { Poole } \\
\text { d }\end{array}$ & $\begin{array}{c}2017 \\
-18\end{array}$ & $\begin{array}{c}2018 \\
-19\end{array}$ & $\begin{array}{c}\text { Poole } \\
\text { d }\end{array}$ & $\begin{array}{c}2017- \\
18\end{array}$ & $\begin{array}{c}2018 \\
-19\end{array}$ & $\begin{array}{c}\text { Poole } \\
\text { d }\end{array}$ & $\begin{array}{c}2017 \\
-18\end{array}$ & $\begin{array}{c}2018 \\
-19\end{array}$ & $\begin{array}{c}\text { Poole } \\
\text { d }\end{array}$ \\
\hline T1 & 4.55 & 4.53 & 4.54 & 1.70 & 1.72 & 1.71 & 0.43 & 0.43 & 0.43 & 1.36 & 1.28 & 1.32 & 25.18 & 24.69 & 24.94 & 67.58 & 69.24 & 68.41 \\
\hline $\mathbf{T 2}$ & 4.50 & 4.58 & 4.54 & 1.71 & 1.74 & 1.72 & 0.42 & 0.42 & 0.42 & 1.26 & 1.34 & 1.30 & 24.32 & 24.51 & 24.42 & 68.43 & 69.17 & 68.80 \\
\hline T3 & 4.54 & 4.56 & 4.55 & 1.74 & 1.75 & 1.74 & 0.43 & 0.43 & 0.43 & 1.27 & 1.35 & 1.31 & 23.72 & 25.71 & 24.72 & 69.10 & 70.24 & 69.67 \\
\hline T4 & 4.54 & 4.58 & 4.56 & 1.75 & 1.77 & 1.76 & 0.42 & 0.42 & 0.44 & 1.28 & 1.38 & 1.33 & 24.94 & 25.09 & 25.02 & 67.91 & 72.09 & 70.00 \\
\hline SE.m & 0.01 & 0.01 & 0.01 & 0.01 & 0.01 & 0.01 & 0.01 & 0.01 & 0.01 & 0.01 & 0.01 & 0.01 & 0.21 & 0.19 & 0.15 & 0.44 & 0.47 & 0.40 \\
\hline \multirow{2}{*}{$\underset{(p=0.05)}{C D}$} & 0.04 & 0.04 & 0.02 & 0.03 & 0.03 & 0.03 & 0.02 & 0.02 & 0.02 & 0.03 & 0.03 & 0.02 & 0.66 & 0.57 & 0.46 & 1.34 & 1.44 & 1.23 \\
\hline & $*$ & $*$ & $*$ & $*$ & $*$ & $*$ & $*$ & $*$ & $*$ & $*$ & $*$ & $*$ & $*$ & $*$ & $*$ & $*$ & $*$ & $*$ \\
\hline
\end{tabular}


Table.4 Economics of tree mulberry leaf production with intercrops

\begin{tabular}{|c|c|c|c|c|}
\hline Particulars & Treatment-1 & Treatment-2 & Treatment-3 & Treatment-4 \\
\hline $\begin{array}{c}\text { Gross Return from } \\
\text { Mulberry (Rs/ha) }\end{array}$ & 38895 & 38175 & 39127 & 39779 \\
\hline $\begin{array}{c}\text { Gross Return from } \\
\text { Intercrop (q/ha) }\end{array}$ & - & 14.5 & 8.51 & 7.5 \\
\hline $\begin{array}{c}\text { Additional Income } \\
\text { (Rs/ha) }\end{array}$ & - & 24650 & 18772 & 28000 \\
\hline $\begin{array}{c}\text { Total Gross Return } \\
\text { (Rs/ha) }\end{array}$ & 38895 & 62825 & 57844 & 67779 \\
\hline $\begin{array}{c}\text { Gross Cost } \\
\text { (Rs/ha) }\end{array}$ & 15300 & 24500 & 23500 & 25700 \\
\hline $\begin{array}{c}\text { Net Return } \\
\text { (Rs/ha) }\end{array}$ & 23595 & 38325 & 34344 & 42079 \\
\hline \begin{tabular}{c} 
BC Ratio \\
\hline $\mathrm{T}_{1}=$ Sole Tree Mulberry \\
Cowpea
\end{tabular} & $\mathrm{T}_{2}=$ Tree Mulberry+ Ragi & $\mathrm{T}_{3}=$ Tree Mulberry + Groundnut & $\mathrm{T}_{4}=$ Tree Mulberry + \\
\hline
\end{tabular}

The results of the present study revealed that the farmers in the study area have been converted to mono cropping to intercropping of tree mulberry with short duration crops with maximum land use which enables the community to diversify their income. Moreover it has helped in the economic upliftment of the farmer in particular.

The intercropping will increase the income of sericulture farmers along with the sericulture activities. It provides multiple outputs, generates income as well as employment, and also protects the soil. Its large scale adoption will help in accomplishing the conservationlinked sustainable development goals in the long run, which helped in doubling the farmer's income. Growing cowpea as intercrop in tree mulberry given more additional income and improved soil fertility.

\section{Acknowledgement}

This study was funded by ICAR - ATARI to conduct OFT for two years and facilities provided by University of Agricultural Sciences, Bengaluru are acknowledged.

\section{References}

Ahasn, M.M., Dhar, K.L., Fotedar, R.K., and Dhar, A. 1989. Studies on the intercropping of short durations crops with mulberry. Indian Journal of Sericulture. 28(2): 194- 199.

Bravo-Monroy, L., Potts, S.G., Tzanopoulos, J. 2016. Drivers influencing farmer decisions for adopting organic or conventional coffee management practices. Food Policy. 58: 49-61.

Current, D., Lutz, E., and Scherr, S.J. 1995. The costs and benefits of agroforestry to farmers. World Bank Res Obs. 10(2): 151-180.

Dayakar Yadav, B.R., and Nagendra Kumar, T.D. 1998. Effect of row arrangement on yield and monetary benefits in mulberry (Morus alba) with soybean (Gycine max) and mulberry with green gram (Phaseolus radiates) intercropping. Indian journal of Agricultural Sciences. 68: 149-151.

De Souza Filho, H.M., Young, T., and Burton, M. P. 1999. Factors influencing the adoption of sustainable agricultural 
technologies: evidence from the State of Espírito Santo, Brazil. Technol Forecast Soc Change. 60(2): 97-112.

Gargi Sukla, P., Kumar, D., Kumar, R., and Pandey, R.K. 1997. Intercropping for profitable in Purvanchal. Indian Silk. 35(11): 31-32

Kabir, N.E., Sinha, A.C., and Ray, D. 1991. Genotype row configuration in the development of an efficient intercropping system in mulberry. Indian Agriculturist. 35(1): 27-32.

Kaur, R., Mir, M.R., Khan, M.A., and Mir, S. 2002. Intercropping of mulberry with saffron. Indian Silk. 41(2): 5-6.

Koul, S., Fotadar, R.K., Dhar, K.L., Anil, and Singhal, B.K. 2008. Suitable crops for intercropping with mulberry in Jammu area. Indian Silk. 46(7): 4-6

Madhusudan Chamoli, V.K., Varshney, P.K., Srinivasan Rajeev Pandey., and Kanta, S. 2015. Intercropping of some medicinal plants with mulberry. Cibtech Journal of Bio-Protocols. 4(1): 2-30.

Moreno, G., Sunding, D.L. 2005. Joint estimation of technology adoption and land allocation with implications for the design of conservation policy. American Journal of Agricultural Economics. 87(4): 1009-1019.

Mushtaq Rasool Mir., Muneesa Banday.,
IrfanLatief Khan., M. F. Baqual and Rameez Raja. 2018. Efficacy of mulberry based intercropping system in the pirpanjal and shiwalik regions of Himalayas, Journal in Science Agriculture \& Engineering. 8(25): 5660.

Russel, D.F. 1986. MSTAT-C package programme. Crop and Soil Science, Department, Michigan State University, USA.

Shankar, M.A., Jayaramaiah, M., Rangaswamy, B.T., Anitha Peter., Lingappa, B.S., and Mallikarjuna, G.B. 1998. Adoption of intercropping system in mulberry. Mysore Journal of Agricultural Sciences. 32: 229-232.

Shankar, M.A., Jayaramaiah, M., Rangaswamy, B.T., Anitha Peter., Lingappa, B.S., and Mallikarjuna, G.B. 2000. Intercropping of pulses and oilseed crop in S13 mulberry under irrigated condition, Abstracts, National Conference on Strategies for Sericulture Research and Development, pp.35-36.

Singhvi, N.R., and Katiyar, R.L. 2009. Performance of moong bean as intercrop in newly planted mulberry garden. International Journal of Plant Sciences. 4(2): 365-366.

\section{How to cite this article:}

Rajegowda, B. S. Vinutha, C. Vanitha and Sanath Kumar, V. B. 2020. Effect of Growing Intercrops on Growth and Yield of Tree Mulberry Inturn its Influence on Cocoon Yield. Int.J.Curr.Microbiol.App.Sci. 9(05): 3134-3139. doi: https://doi.org/10.20546/ijcmas.2020.905.371 